\title{
Anadolu adaçayı (Salvia fruticosa Mill.) tohumu çimlenmesine ön üşütme süreleri ve farklı gibberellik asit dozlarının etkisi
}

\section{The effects of pre-cold soaking and different concentration of gibberellic acid on sage (Salvia fruticosa Mill.) seeds germinations}

\author{
Melike BEKEN ${ }^{1}$ iD Abdulhabip ÖZEL $^{2 *}$ iD \\ ${ }^{1}$ Harran Üniversitesi Fen Bilimleri Enstitüsü, Tarla Bitkileri Anabilim Dalı, 63040, Şanlıurfa \\ ${ }^{2}$ Harran Üniversitesi Ziraat Fakültesi Tarla Bitkileri Bölümü, 63040, Şanlıurfa \\ ${ }^{1}$ https://orcid.org/0000-0002-9789-9715; ${ }^{2}$ https://orcid.org/0000-0002-3605-2596
}

To cite this article:

Beken, M. \& Özel, A. (2021). Anadolu adaçayı (Salvia fruticosa Mill.) tohumu çimlenmesine ön üşütme süreleri ve farklı gibberellik asit dozlarının etkisi. Harran Tarım ve Gıda Bilimleri Dergisi, 25(4): 514525.

DOI: 10.29050/harranziraat.865924

*Address for Correspondence: Abdulhabip ÖZEL

e-mail:

hozel@harran.edu.tr

Received Date:

25.01.2021

Accepted Date:

19.11.2021

(C) Copyright 2018 by Harran University Faculty of Agriculture. Available on-line at www.dergipark.gov.tr/harranziraat

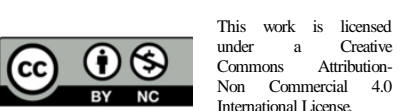

öz

Çalışma, Anadolu adaçayı (Salvia fruticosa Mill.) tohumlarının çimlenme ve fide kalitesi üzerine ön üşütme (Stratifikasyon) süresi uygulamaları (kontrol, 14 gün, 28 gün ve 42 gün, $+4{ }^{\circ} \mathrm{C}$ sıcaklıkta) ve gibberellik asit ( $\left.\mathrm{GA}_{3}\right)$ konsantrasyonu $(0$ ppm, 100 ppm, 200 ppm, 300 ppm ve 400 ppm) uygulamalarının, tek ve birleşik etkilerini belirlemek amacıyla yürütülmüştür. Çalışma 2018 yılında, Harran Üniversitesi, Ziraat Fakültesi, Tarla Bitkileri Bölümü laboratuvarında bulunan çimlendirme dolaplarında yürütülmüştür. Deneme Tesadüf Parsellerinde Bölünmüş Parseller Deneme Desenine göre 3 tekerrürlü olarak kurulmuş ve ana parsellere ön üşütme süresi, alt parsellere $\mathrm{GA}_{3}$ dozları olacak şekilde düzenlenmiştir. Bulgulara göre, çimlenme hızı, çimlenme gücü, fide sürgün uzunluğu, fide kök uzunluğu, fide kuru ağırlığı, sürgün kuru ağırlığı ve kök kuru ağırlığının stratifikasyon uygulamalarının ve $\mathrm{GA}_{3}$ uygulamalarının, tek ve birleşik etkilerinden önemli derecede etkilendiği belirlenmiştir. Çimlenme gücünün yüksek olduğu 100 ppm GA ve $_{3} 14$ gün ön üşütme uygulamasının tohum çimlenmesi için uygun olduğu sonucuna varılmıştır.

Anahtar Kelimeler: Salvia fruticosa, Çimlenme, GA3, Stratifikasyon

\section{ABSTRACT}

This study was carried out to determine the single and combined effects of different stratification (pre-chilling periods) (control, 14 days, 28 days, and 42 days at $+4{ }^{\circ} \mathrm{C}$ degree) and different gibberellic acid concentrations ( 0 ppm, 100, ppm, 200 ppm, 300 ppm and, 400 ppm) applications on the germination and seedling quality of Anatolian sage (Salvia fruticosa Mill.) seeds. The study was conducted in the germination cabinets at Harran University, Faculty of Agriculture, Department of Field Crops Laboratory in 2018. The experiment was set up according to the Randomized Complete Plot with Split-plot design with 3 replications, prechilling periods was the main plot, and $\mathrm{GA}_{3}$ doses to the subplot. Speed of germination, germination power, seedling sprout length, seedling root length, dry seedling weight, dry sprout weight and dry root weight was significantly affected from the single and combined effects of stratification (pre-chilling time) and gibberellic acid applications. It was concluded that $100 \mathrm{ppm} \mathrm{GA}_{3}$ and 14 days pre-chill application are suitable for highest germination power.

Key Words: Salvia fruticosa, Germination, $\mathrm{GA}_{3}$, Stratification

\section{Giriş}

Lamiaceae (Ballıbabagiller) familyasına bağlı en büyük cinslerden biri olan Salvia'nın dünyada 900 türü bulunmakta olup bunlar genellikle Amerika, Güney-Batı Asya ve Afrika kıtalarında yayılış göstermektedir. Türkiye'de ise Salvia cinsine bağlı 
97 tür, 4 alt tür ve 8 varyetesi bulunmaktadır (Karık, 2013).

Adaçayı ülkemizde dış satımı yapılan önemli bir tür olup, Türkiye'de 2018 yılında 1961 ton adaçayı ihracatı yapılmıştır (Kırıcı ve ark., 2020). Ticari değeri yüksek olan 5 Salvia türü vardır. Bunlar; Salvia officinalis L., S. fruticosa Mill., S. pomifera L. ve S. sclarea L.'dir (Dweck, 2000).

Bunlardan Salvia fruticosa Mill. (Anadolu adaçayı) Türkiye'de hem iç tüketimde kullanılan hem de yaprakları ihraç edilen önemli bir adaçayı türüdür (Bayram ve Sönmez, 2006). Anadolu adaçayı çok yıllık, çalı formunda, yaprakları genellikle basit yapılı, çiçekleri açık eflatun renginde ve bazen de beyaz olan, mart-mayıs aylarında çiçek açan bir bitkidir (Karık ve Sağlam, 2017). Bu bitkinin saplarında elmaya benzeyen mazıların bulunması nedeniyle, bitkinin yapraklarından elde edilen uçucu yağ, halk arasında, elma yağı olarak adlandırılır (Bayram ve Sönmez, 2006). Doğal ortamından toplanan bitkilerin kuru yapraklarında \%2-3 oranında uçucu yağ bulunmaktadır. Bu yağın ana bileşeni 1,8cineole olup, \%20.7-46.9 arasında değiştiği, bunun yanında yağın bileşimindeki camphor oranının \%2.8-17.5, $\beta$-pinene oranın ise \%5.3-11.3 arasında değiştiği belirlenmiştir (Karık ve Sağlam, 2018). Anadolu adaçayından elde edilen uçucu yağın bileşiminde thujon oranı tıbbi adaçayına göre düşük olduğu için Anadolu adaçayı çay şeklinde kullanılmaya daha uygun bir tür olarak bilinmektedir (Zeybek ve Zeybek, 1994; Karık, 2013).

Adaçayı, Mezopotamya'da 6000 yı öncesinden bu yana şifa amacıyla kullanılan önemli bir tıbbi ve aromatik bitkidir. Adaçayının kuru yaprakları ve çiçekleri bazı ilaçların yapımında, gövde ve yaprakları boyacılıkta, bazı türleri ise süs amacıyla kullanılmaktadır. Adaçayı özelikle ağrı kesici, soğuk algınlığı, sara hastalığı, bronşit, verem, menstrual rahatsızlıklar ve kanamaların tedavisi için kullanılmaktadır (Rivera ve ark., 1994; Topçu, 2006; Karık, 2013). Anadolu adaçayının ise unutkanlığı azaltıcı, soğuk algınlığında vücudu ısıtıcı, adet düzenleyici, cilt sarkmasını azaltıcı etkileri bulunmaktadır (Zeybek ve Zeybek, 1994;
Karık, 2013).

İnsanlar tarih boyunca birçok hastalığın tedavisinde bitkilerden faydalanmışlardır. Özellikle 1990'lı yıllardan sonra tıbbi ve aromatik bitkilerin yeni kullanım alanlarının keşfedilmesi, bu bitkilerin kullanım hacmini arttırmıştır (Kırıcı ve ark., 2020). Insanlar bu bitkileri daha çok doğal ortamından toplayarak elde etmektedir. Ancak doğal ortamından toplanan bitkilerde kaliteli ve standartlara uygun ürün elde etmek zordur. Bu nedenle bu bitkileri kültüre alarak kaliteli ve standartlara uygun ürün elde etmek mümkündür (Kırıcı ve ark., 2020). Anadolu adaçayı ülkemizde hem iç tüketimde kullanılan hem de ihracatı yapılan önemli bir tıbbi ve aromatik bitkidir (Karık, 2013). Ancak birçok tıbbi bitkide olduğu gibi, adaçayı da daha çok doğal ortamından toplanarak elde edilmekte, az bir kısmının ise kültürü yapılmaktadır. Karık ve ark. (2013), Anadolu adaçayında standartlara uygun ürün elde edilebilmesi için bu türün kültüre alınması gerektiğini bildirmiştir.

Kültürü yapılan bitkilerde, kaliteli ve verimli üretimin en önemli girdilerinden biri kullanılan tohumluktur. Diğer tüm girdiler ise tohumluğun üretim kapasitesini ortaya çıkarmasına yardımcı olan unsurlardır (Yılmaz, 2008; Şehirali, 2002; Tulukçu, 2012). Birim alandan yüksek verim alınabilmesi için öncelikle tohumun çimlenmesi ve homojen bir çıkışın sağlanması gerekir. Bunun içinde tohumların çimlenme isteklerinin bilinmesi faydalı olacaktır (Sönmez ve ark., 2019). Anadolu adaçayı tohumlarında çimlenme problemleri olduğu için, bu sorunu çözecek bazı uygulamaların bilinmesi avantaj sağlayacaktır. Dormasiyi kaldırmada, sıklıkla stratifikasyon (ön üşütme) ve giberilik asit $\left(\mathrm{GA}_{3}\right)$ uygulamaları kullanılmaktadır. Stratifikasyon işlemi tohumlarda çimlenmeyi teşvik etmek amacıyla tohumların nemli ve serin ortam koşullarında bekletilmesi işlemidir. $\mathrm{GA}_{3}$ tohumdaki depo maddelerini aktif hale getirerek tohum çimlenmesini uyarmaktadır. Ön üşütme işlemi aynı zamanda $\mathrm{GA}_{3}$ miktarını arttırıp, $\mathrm{ABA}$ miktarını azalttığı için çimlenmeyi olumlu yönde etkilemektedir (Ünal ve ark., 2004). Bu konuda yapılan çalışmalarda, Sönmez ve ark. (2019) 
adaçayı tohumlarının musilajımsı tohum kabuğuna sahip olduğunu ve bunun dormansiye neden olduğunu, tohumlardaki dormansiyi kırmak için $\mathrm{KNO}_{3}, \mathrm{GA}_{3}$ ve polimer kaplama gibi uygulamalar yapılabileceğini ve $\mathrm{GA}_{3}$ uygulamalarının çimlenmeyi artırdığını, Subaşı ve Güvensen (2010) İzmir adaçayı (S. smyrnaea) tohumlarında $\mathrm{GA}_{3}$ ve stratifikasyonun uygulamalarının çimlenme için gerekli olduğunu, Finch ve ark. (1991) 7 farklı Salvia türünde yaptıkları bir çalışmada $\mathrm{GA}_{3}$ uygulamalarının çimlenmeye etkisinin olmadığını bildirmişlerdir. Ayrıca, Weerakoon ve Lovett (1986) S. reflexa tohumlarında dormansi olduğunu ve bu dormansiyi kırmak için tohumların nemli olarak 2 hafta $10{ }^{\circ} \mathrm{C}$ sıcaklıkta ve daha sonra 2 saat $40{ }^{\circ} \mathrm{C}$ sıcaklıkta bekletilmesi gerektiğini, Şenel (2005) S. dicroantha türüne ait tohumların en iyi $20{ }^{\circ} \mathrm{C}$ sıcaklıkta çimlendiğini ve farklı $\mathrm{GA}_{3}$ doz uygulamalarında $\left(20,100\right.$ ve $\left.200 \mathrm{mg} \mathrm{l}^{-1}\right)$ çimlenme olmadığını, Subaşı ve Güvensen (2010) S. smyrnaea (Izmir adaçayı) tohumlarında dormansinin kırılması için stratifikasyonun tek başına yeterli olmadığını, $\mathrm{GA}_{3}{ }^{\prime}$ ün de gerekli olduğunu, en iyi çimlenmenin stratifikasyon ve 250 ppm $\mathrm{GA}_{3}$ uygulanmış tohumlardan elde etiklerini, Abdollahi ve ark. (2011) bazı Salvia türleri tohumlarında gibberellik asidin bazı türlerde çimlenme yüzdesini artırdığını buna karşılık bazı türlerde ise çimlenin olmadığını, Özcan ve ark. (2014) çimlenme değerleri bakımından türler arasında farklılıkların olduğunu, S. fruticosa Mill. tohumlarında en iyi çimlenme değerinin ön üşütme uygulamasında ve $\mathrm{GA}_{3}$ uygulamasında elde ettiklerini, Sönmez ve ark. (2019) S. fruticosa Mill. tohumlarında $\mathrm{GA}_{3}$ uygulamasında kontrole göre daha yüksek çimlenme oranı elde edildiğini bildirmişlerdir. Anadolu adaçayı tohumları çimlenme problemlerinin giderilmesi konusunda bilgi birikimi oldukça kısıtlı olup tohumdan, adaçayı üretmek isteyen çiftçilere ve araştırmacılara bilgi birikimi oluşturmak önem arz etmektedir.

$\mathrm{Bu}$ çalışma, Anadolu adaçayı tohumlarının çimlenme ve fide kalitesi üzerine stratifikasyon (ön üşütme) ve gibberellik asit $\left(\mathrm{GA}_{3}\right)$ uygulamalarının, tek ve birleşik etkisini belirlemek amacıyla yürütülmüştür.

\section{Materyal ve Yöntem}

Araştırmada, Yalova Atatürk Bahçe Kültürleri Merkez Araştırma Enstitüsü Müdürlüğünden temin edilen Salvia fruticosa Mill. (Anadolu adaçayı) türüne ait tohumlar kullanılmıştır. Tohumlar, doğal floradan toplanarak seleksiyona tabi tutulmuş popülasyonlardan elde edilen bitkilerden sağlanmış ve yeni mahsul olup (2018), bin tane ağırlığı $4.75 \mathrm{~g}$ olarak belirlenmiştir. Gibberellik asit $\left(\mathrm{GA}_{3}\right)$ dozları, toz gibberellik asit (Sigma-Aldrich CAS-NO:77-06-5) kullanılarak hazırlanmış ve çimlenme denemesi, otomatik ISI, nem ve ışık kontrollü, GC 450, bitki büyütme dolabında yürütülmüştür.

Bu çalışma, 2018-2019 kış döneminde, Harran Üniversitesi, Ziraat Fakültesi, Tarla Bitkileri laboratuvarında yürütülmüştür. Çalışmada, Anadolu adaçayı tohumları 4 farklı ön üşütme süresi (kontrol, 14 gün, 28 gün ve 42 gün, $+4{ }^{\circ} \mathrm{C}$ sıcaklıkta bekletme) ve 5 farklı $\mathrm{GA}_{3}$ dozlarına (0, $100,200,300$ ve 400 ppm $\mathrm{GA}_{3}$ çözeltilerinde 24 saat bekletme) tabi tutularak, bunların çimlenme ve ilgili parametrelere etkisi belirlenmiştir.

Deneme, Tesadüf Parsellerinde, Bölünmüş Parseller Deneme Desenine göre 3 tekerrürlü olarak kurulmuş ve ana parsellere ön üşütme süreleri, alt parsellere $\mathrm{GA}_{3}$ dozları gelecek şekilde düzenlenmiştir.

\section{Ön üşütme uygulaması}

Anadolu adaçayı tohumları ön üşütme uygulamasından önce \%5'lik sodyum hipoklorit çözeltisi içinde 5 dakika tutularak sterilizasyon işlemi yapılmış ve tohumlar saf su ile 3 defa durulanmıştır. Daha sonra, tohumlar nemlendirilmiş 2 kat kurutma kâğıdı arasında, cam saklama kaplarına konulmuş ve $+4{ }^{\circ} \mathrm{C}$ de 14 , 28 ve 42 gün süreyle bekletilerek ön üşütme işlemine tabi tutulmuştur (Tuncer ve Ummuhan, 2017). Kontrol gruplarında ön üşütme işlemi yapılmamıştır. 


\section{$G A_{3}$ uygulaması}

Toz halindeki $\mathrm{GA}_{3}{ }^{\prime}$ ten $200 \mathrm{mg}$ tartılarak üzerine $10 \mathrm{ml}$ alkol eklenerek, eritilmiş ve daha sonra $\mathrm{GA}_{3}$ çözeltisi üzerine uygulamalara göre, saf su eklenerek 100, 200, 300 ve 400 ppm GA dozları hazırlanmıştır.

Ön üşütme işlemi uygulanan ve kontrol grubu tohumları 24 saat, hazırlanan $0,100,200,300$ ve 400 ppm $\mathrm{GA}_{3}$ dozlarında bekletildikten sonra çimlenme dolabına alınarak deneme yürütülmüştür.

Çimlendirme işlemi; denemede toplam 3000 adet tohum kullanılmış ve her uygulama için üç tekrarlamalı olacak şekilde, cam petrilere $(10 \mathrm{~cm})$, kurutma kağıdı arasına 50 adet tohum yerleştirilmiş ve tohumlar petri kaplarına konulmadan önce kurutma kağıtları saf su ile ıslatılmıştır. Çalışmada kullanılan tüm malzemeler (petri, kurutma kağıdı, pens vb.) önce, etüvde 105 ${ }^{\circ} \mathrm{C}$ de, sterilize edilmiştir.

Petri kaplarına yerleştirilen tohumlar, nemi (\%70), sıcaklığı $\left(25 / 15^{\circ} \mathrm{C}\right)$ ve ışıklanma süreleri (12 saat aydınlık ve 12 saat karanlık ortamda) ayarlanmış çimlenme dolaplarında, çimlenme testlerine tabi tutulmuştur (Özcan ve ark., 2014).

Anadolu adaçayı tohumlarında çimlenme hızı ve çimlenme gücünü belirlemek için ön deneme yapılmıştır. Buna göre 14. günde çimlenme hızı ve 24. günde çimlenme gücü sayımlarının yapılmasına karar verilmiştir. Aşağıda belirtilen özellikler Şenel (2005)'in bildirdiği yöntemlere göre yürütülmüştür.

\section{Çimlenme hızı (\%)}

Çalışmada uygulamalara göre her petride, 14. güne kadar çimlenen toplam tohum sayıları belirlenmiş ve toplam tohum sayılarına göre \% olarak hesaplanmıştır.

\section{Çimlenme güсü (\%)}

Çalışmada uygulamalara göre her petride, 24. güne kadar çimlenen tohum sayıları belirlenmiş ve toplam tohum sayılarına göre \% olarak hesaplanmıştır.
Fide sürgün uzunluğu $(\mathrm{cm})$

Her parselden 14 . ve 24. günlerde alınan 5 bitkide, kök boğazı ile en uçtaki yaprak ucu arasındaki mesafe cetvelle ölçülerek, ortalamaları (cm) hesaplanmıştır.

Fide kök uzunluğu $(\mathrm{cm})$

Her parselden 14 . ve 24 . günde alınan 5 bitkide, kök boğazı ile kök ucu arasındaki mesafe cetvelle ölçülerek, ortalamaları (cm) hesaplanmıştır.

\section{Fide kuru ağırlığı (mg)}

Fideler etüvde $70{ }^{\circ} \mathrm{C}$ de 48 saat kurutulduktan sonra tartılarak, kuru ağırlıkları (mg) belirlenmiştir.

\section{Sürgün kuru ağırlığı (mg)}

Kök boğazından ayrılan sürgünler $70^{\circ} \mathrm{C}$ de 48 saat kurutulduktan sonra tartılarak, kuru ağırıkları (mg) belirlenmiştir.

\section{Kök kuru ağırlığı (mg)}

Kök boğazından ayrılan kökler $70^{\circ} \mathrm{C}^{\prime}$ de 48 saat kurutulduktan sonra tekrar tartılarak, kuru ağırlıkları (mg) belirlenmiştir.

Fide ile ilgili gözlemlerde yeterli çimlenmenin olmadığı uygulamalarda, gözlemler oluşan fidelerden alınarak ortalamaları hesaplanmıştır.

Elde edilen veriler, tesadüf parsellerinde bölünmüş parseller deneme desenine göre, MSTAT-C paket programı kullanılarak varyans analizine tabi tutulmuş, önemli çıkan ortalamalar Lsd (\%5)'e göre gruplandırılmıştır.

\section{Araştırma Bulguları ve Tartışma}

\section{Çimlenme hızı}

Anadolu adaçayı tohumlarının çimlenme hızı üzerine, ön üşütme süreleri ana etkilerinin ve ön üşütme süresi $x \quad \mathrm{GA}_{3}$ dozları interaksiyon etkilerinin önemli düzeyde etkili olduğu, $\mathrm{GA}_{3}$ doz uygulamalarının ise istatistiksel anlamda önemsiz olduğu saptanmıştır. Farklı ön üşütme süreleri ve $\mathrm{GA}_{3}$ dozlarında saptanan çimlenme hızı ortalama değerleri (\%) ve oluşan gruplar Çizelge 1'de verilmiştir. 
Çizelge 1. Anadolu adaçayı (Salvia fruticosa Mill.) tohumlarının farklı ön üşütme süreleri ve GA $\mathrm{G}_{3}$ dozlarında saptanan çimlenme hızı ortalamaları (\%) ve oluşan gruplar

Table 1. Average speed of germination (\%, first count, $14^{\text {th }}$ day) determined in the application of different stratification periods and gibberellic acid concentrations and created groups

\begin{tabular}{|c|c|c|c|c|c|}
\hline \multirow{2}{*}{$\begin{array}{l}\mathrm{GA}_{3} \text { dozları } \\
G A_{3} \text { doses }\end{array}$} & \multicolumn{4}{|c|}{$\begin{array}{l}\text { Ön üşütme süresi } \\
\text { Pre-chilling periods }\end{array}$} & \multirow{2}{*}{$\begin{array}{l}\text { Ortalama } \\
\text { Average }\end{array}$} \\
\hline & Kontrol/Control & 14 gün/day & 28 gün/day & 42 gün/day & \\
\hline Kontrol/Control & $17.33 \mathrm{~b}-\mathrm{e}$ & $13.33 \mathrm{c}-\mathrm{f}$ & $21.33 \mathrm{bcd}$ & $14.00 \mathrm{c}-\mathrm{f}$ & 16.50 \\
\hline 100 ppm & $11.33 \mathrm{def}$ & $17.33 \mathrm{~b}-\mathrm{e}$ & $18.00 \mathrm{~b}-\mathrm{e}$ & $8.66 \mathrm{efg}$ & 13.83 \\
\hline 200 ppm & $12.00 \mathrm{def}$ & $23.33 a b c$ & 12.00 def & $3.33 \mathrm{fg}$ & 12.66 \\
\hline 300 ppm & $8.66 \mathrm{efg}$ & $33.33 \mathrm{a}$ & $4.00 \mathrm{fg}$ & $4.00 \mathrm{fg}$ & 12.50 \\
\hline 400 ppm & 8.00 efg & $28.00 \mathrm{ab}$ & $4.00 \mathrm{fg}$ & $0.00 \mathrm{~g}$ & 10.00 \\
\hline Ortalama/Average & $11.46 \mathrm{~B}$ & $23.06 \mathrm{~A}$ & $11.86 \mathrm{~B}$ & $6.00 \mathrm{~B}$ & \\
\hline LSD (\%) & \multicolumn{5}{|c|}{$\begin{array}{l}6.00 \text { (Ön Üşütme Süresi/Pre-chilling periods), } \\
11.08 \text { (Ön Üşütme Süresi x GA } A_{3} \text { Dozları/Pre-chilling periods } x G_{3} \text { doses) }\end{array}$} \\
\hline
\end{tabular}

Çizelge 1'de, farklı ön üşütme sürelerine göre ortalama çimlenme hızı değerlerinin \% 6.00-23.06 arasında değiştiği, en yüksek çimlenme hızı ortalama değerinin 14 gün ön üşütme, en düşük çimlenme hızı ortalama değeri ise 42 gün ön üşütme uygulamasında saptandığı; farklı ön üşütme süreleri $x \mathrm{GA}_{3}$ dozları birlikte etkileri incelendiğinde çimlenme hızı ortalama değerlerinin \%0.00-33.33 arasında değiştiği, en yüksek çimlenme hızı ortalama değerinin 14 gün ön üşütme x 300 ppm $\mathrm{GA}_{3}$ uygulamasında, en düşük çimlenme hızı ortalama değerinin ise 42 gün ön üşütme x 400 ppm $\mathrm{GA}_{3}$ uygulamasında saptandığı görülmektedir. Ayrıca önemli olmamakla beraber, $\mathrm{GA}_{3}$ dozlarına göre ortalama çimlenme hızı değerlerinin \%10.00-16.50 arasında değiştiği ve en yüksek oranın kontrolden elde edildiği ve artan dozların çimlenme hızını olumsuz etkilediği görülmektedir. Genel olarak, farklı $\mathrm{GA}_{3}$ doz uygulamaları ve 14 günden fazla uygulanan stratifikasyon sürelerinin çimlenme hızını olumsuz etkilemiş olduğu, $\mathrm{GA}_{3}$ ve stratifikasyon birleşik etkilerinin çimlenme hızını farklı biçimlerde etkilediği söylenebilir. En yüksek ortalama çimlenme hızı değeri 14 gün ön üşütme x 300 ppm $\mathrm{GA}_{3}$ uygulamasından alınmış ve daha uzun süreli ön üşütme uygulamaları ve $\mathrm{GA}_{3}$ uygulamaları çimlenme hızı değerini olumsuz etkilemiştir.

Bulgularımız ön üşütme uygulamalarının çimlenme hızını olumlu yönde etkilediğini bildiren bazı araştırmacıların (Özcan ve ark., 2014) bulgularıyla benzerlik göstermektedir. Aynı zamanda soğuk katlama uygulamalarında, uygulama süresinin artmasının çimlenme hızını olumsuz etkilediğini bildiren Göktürk ve ark. (2007)'nın çalışmalarıyla uyumlu bulunmuştur.

$\mathrm{GA}_{3}$ uygulamalarının ise çimlenme hızını önemli düzeyde etkilememesi bazı araştırıcıların (Yücel ve Yılmaz, 2009; Çavuşoğlu ve ark., 2010; Hayta ve Arabacı, 2011) bulgulariyla uyumlu bulunurken, $\mathrm{GA}_{3}$ uygulamalarının çimlenmeyi olumlu yönde etkilediğini bildiren bazı araştırıcıların (Özcan ve ark., 2014; Arabacı ve ark., 2014; Çalışkan ve ark., 2016) bulgularıyla çelişmektedir. Bu durum, genotip farklılığından, tohumun canlılığından veya tohumun elde edildiği ana bitkinin maruz kaldığı yetiştirilme koşullarından kaynaklandığı düşünülmektedir.

Hızlı bir çimlenmede, 14 gün ön üşütme $x 300$ ppm $\mathrm{GA}_{3}$ uygulamasının daha iyi sonuç verdiği görülmektedir.

\section{Çimlenme gücü}

Anadolu adaçayı tohumlarının çimlenme gücü üzerine, ön üşütme süreleri ana etkilerinin önemli düzeyde etkili olduğu, $\mathrm{GA}_{3}$ doz uygulamaları ve ön üşütme süresi $x \quad G_{3}$ dozları interaksiyon etkilerinin ise istatistiksel anlamda önemsiz olduğu belirlenmiştir. Farklı ön üşütme süreleri ve $\mathrm{GA}_{3}$ dozlarında saptanan çimlenme gücü ortalama (\%) değerleri ve oluşan gruplar Çizelge 2'te verilmiştir. 
Çizelge 2. Anadolu adaçayı (Salvia fruticosa Mill.) tohumlarının farklı ön üşütme süreleri ve $\mathrm{GA}_{3}$ dozlarında saptanan çimlenme gücü ortalamaları (\%) ve oluşan gruplar

Table 2. Average germination power $\left(\%\right.$, second count, $24^{\text {th }}$ day) determined in the application of different stratification periods and gibberellic acid concentrations and created groups

\begin{tabular}{|c|c|c|c|c|c|}
\hline \multirow{2}{*}{$\begin{array}{l}\mathrm{GA}_{3} \text { dozları } \\
\mathrm{GA} A_{3} \text { doses }\end{array}$} & \multicolumn{4}{|c|}{$\begin{array}{l}\text { Ön üşütme süresi } \\
\text { Pre-chilling periods }\end{array}$} & \multirow{2}{*}{$\begin{array}{l}\text { Ortalama } \\
\text { Average }\end{array}$} \\
\hline & Kontrol/Control & 14 gün/day & 28 gün/day & 42 gün/day & \\
\hline Kontrol/Control & 29.33 & 25.33 & 28.66 & 22.66 & 26.50 \\
\hline 100 ppm & 19.33 & 48.66 & 30.00 & 24.66 & 30.66 \\
\hline 200 ppm & 18.66 & 41.33 & 24.66 & 14.00 & 24.66 \\
\hline 300 ppm & 20.00 & 42.66 & 14.00 & 15.33 & 23.00 \\
\hline 400 ppm & 20.00 & 40.66 & 7.33 & 1.33 & 17.33 \\
\hline Ortalama/Average & $21.46 \mathrm{~B}$ & $39.73 \mathrm{~A}$ & 20.93 B & $15.60 \mathrm{~B}$ & \\
\hline LSD (\%) & \multicolumn{5}{|c|}{8.27 (Ön Üşütme Süresi/Pre-chilling periods) } \\
\hline
\end{tabular}

Çizelge 2'te, farklı ön üşütme sürelerine göre ortalama çimlenme gücü değerlerinin \% 15.6039.73 arasında değiştiği, en yüksek çimlenme gücü ortalama değerinin 14 gün ön üşütme, en düşük çimlenme gücü ortalama değerinin ise 42 gün ön üşütme uygulamasında saptandığı; farklı ön üşütme süreleri $x \mathrm{GA}_{3}$ dozları birlikte etkileri incelendiğinde ortalama çimlenme gücü değerlerinin \%1.33-48.66 arasında değiştiği, en yüksek çimlenme gücü ortalama değerinin 14 gün ön üşütme x 100 ppm $\mathrm{GA}_{3}$ uygulamasından, en düşük çimlenme gücü ortalama değerinin ise 42 gün ön üşütme x 400 ppm $\mathrm{GA}_{3}$ uygulamasında saptandığı ve farklı $\mathrm{GA}_{3}$ dozlarına göre ortalama çimlenme gücü değerlerinin \%17.33-30.66 arasında değiştiği ve en yüksek oranın 100 ppm $\mathrm{GA}_{3}$ uygulamasından elde edildiği ve artan dozların çimlenme gücünü olumsuz etkilediği görülmektedir. En yüksek çimlenme gücü ortalama değeri 14 gün ön üşütme x 100 ppm GA GA $_{3}$ uygulamasından alınmış ve daha uzun süreli ön üşütme uygulamaları ve $\mathrm{GA}_{3}$ uygulamaları çimlenme gücü ortalama değerlerini olumsuz etkilemiştir. Kontrole göre ortalama çimlenme gücü değerinin (\%29.33), yüksek $\mathrm{GA}_{3}$ konsantrasyonu ve uzun stratifikasyon uygulamasından olumsuz yönde etkilendiği (\%1.33) belirlenmiştir. 14 gün ön üşütme $\times 100$ ppm $\mathrm{GA}_{3}$ uygulamasına kadar ortalama çimlenme gücü değeri artarken, daha yüksek $\mathrm{GA}_{3}$ dozu ve daha uzun stratifikasyon süreleri çimlenme gücü ortalama değerlerini kademeli olarak düşürmüştür. Yüksek $\mathrm{GA}_{3}{ }^{\prime}$ ün çimlenmeyi olumsuz etkilediği tespit edilmiştir. Nitekim, Ünal ve ark. (2004) ön üşütmenin aynı zamanda $\mathrm{GA}_{3}$ sentezini arttırdığını ve Şubaşı ve Güvensoy (2010) ise yüksek $\mathrm{GA}_{3}$ konsantrasyonlarının çimlenmeyi olumsuz yönde etkilediklerini bildirmektedirler.

Bulgularımız ön üşütme uygulamalarının çimlenme gücünü olumlu yönde etkilediğini bildiren bazı araştırıcıların (Ünal ve ark., 2004; Temel ve Tokur, 2005; Yücel ve Yılmaz, 2009; Subaşı ve Güvensen, 2010; Özcan ve ark., 2014; Arslan ve ark., 2017; Tuncer ve Ummuhan, 2017;) bulgularıyla benzerlik göstermektedir. Aynı zamanda soğuk katlama uygulamalarında, uygulama süresinin artmasının çimlenme oranını olumsuz etkilediğini bildiren Köse (2000)'nin çalışmasıyla uyumlu bulunmuştur.

Çimlenme gücü değerinin 100 ppm GA uygulamasına kadar arttığını ve daha yüksek dozlardan olumsuz yönde etkilendiğini bildiren bazı araştırmacıların (Bağçe, 2006; Göztaş, 2008; Subaşı ve Güvensen, 2010; Arabacı ve ark., 2014) bulgularıyla, $\mathrm{GA}_{3}$ uygulamalarının çimlenme gücünü önemli düzeyde etkilemediğini bildiren bazı araştırıcıların (Şenel, 2005; Çavuşoğlu ve ark., 2010; Hayta ve Arabacı, 2011; Arslan ve ark., 2017) bulgularıyla ve $\mathrm{GA}_{3}$ uygulamalarının çimlenmeyi olumlu yönde etkilediğini bildiren bazı araştırıcıların (Özcan ve ark., 2014; Tursun, 2019; Sönmez ve ark., 2019) bulgularıyla kısmen uyumlu bulunmuştur. Bulgularla literatür bildirimleri arasındaki kimi çelişki, genotip farklılığından veya tohumun elde edildiği ana bitkinin maruz kaldığı yetiştirilme koşullarından kaynaklanabilir.

\section{Fide sürgün uzunluğu}

Anadolu adaçayı fidelerinde sürgün uzunluğu (cm) üzerine, ön üşütme süreleri ve $\mathrm{GA}_{3} \mathrm{doz}$ 
uygulamaları ana etkilerinin önemli düzeyde etkili olduğu, ön üşütme süresi $\times \mathrm{GA}_{3}$ dozları interaksiyon etkilerinin ise istatistiksel anlamda önemsiz olduğu görülmüştür. Farklı ön üşütme süreleri ve $\mathrm{GA}_{3}$ dozlarında saptanan fide sürgün uzunluğu $(\mathrm{cm})$ ortalama değerleri ve oluşan gruplar Çizelge 3'te verilmiştir.

Çizelge 3. Anadolu adaçayı (Salvia fruticosa Mill.) tohumlarının farklı ön üşütme süreleri ve $\mathrm{GA}_{3}$ dozlarında saptanan fide sürgün uzunluğu $(\mathrm{cm})$ ortalamaları ve oluşan gruplar

Table 3. Average seedling sprout length determined in the application of different stratification periods and gibberellic acid concentrations and created groups

\begin{tabular}{|c|c|c|c|c|c|}
\hline \multirow{2}{*}{$\begin{array}{c}\mathrm{GA}_{3} \text { dozları } \\
G A_{3} \text { doses }\end{array}$} & \multicolumn{4}{|c|}{$\begin{array}{l}\text { Ön üşütme süresi } \\
\text { Pre-chilling periods }\end{array}$} & \multirow{2}{*}{$\begin{array}{l}\text { Ortalama } \\
\text { Average }\end{array}$} \\
\hline & Kontrol/Control & 14 gün/day & 28 gün/day & 42 gün/day & \\
\hline Kontrol/Control & 1.08 & 0.96 & 0.95 & 0.75 & $0.93 \mathrm{~B}$ \\
\hline 100 ppm & 2.66 & 2.13 & 1.45 & 1.78 & $2.01 \mathrm{~A}$ \\
\hline 200 ppm & 1.96 & 2.36 & 1.59 & 1.46 & $1.84 \mathrm{~A}$ \\
\hline 300 ppm & 1.80 & 2.29 & 1.59 & 1.48 & $1.79 \mathrm{~A}$ \\
\hline 400 ppm & 1.91 & 2.34 & $1.83^{1}$ & $0.63^{2}$ & $1.68 \mathrm{~A}$ \\
\hline Ortalama/Average & $1.88 \mathrm{~A}$ & $2.01 \mathrm{~A}$ & $1.48 \mathrm{~B}$ & $1.22 \mathrm{~B}$ & \\
\hline LSD (\%) & \multicolumn{5}{|c|}{0.40 (Ön Üşütme Süresi/Pre-chilling periods), 0.35 (GA $\mathrm{GA}_{3}$ Dozları/GA $A_{3}$ doses) } \\
\hline
\end{tabular}

Çizelge 3'te, farklı ön üşütme sürelerine göre ortalama fide sürgün uzunluğu değerlerinin 1.22$2.01 \mathrm{~cm}$ arasında değiş̧iği, en yüksek fide sürgün uzunluğu ortalama değerinin 14 gün ön üşütme uygulamasında, en düşük fide sürgün uzunluğu ortalama değerinin ise 42 gün ön üşütme uygulamasında saptandığı; farklı $\mathrm{GA}_{3}$ uygulamalarına göre ortalama fide sürgün uzunluğu değerlerinin $0.93-2.01 \mathrm{~cm}$ arasında değiştiği, en yüksek fide sürgün uzunluğu ortalama değerinin 100 ppm uygulamasında, en düşük fide sürgün uzunluğu ortalama değerinin ise kontrolde saptandığı ve farklı ön üşütme süreleri $\mathrm{x} \quad \mathrm{GA}_{3}$ dozları birlikte etkileri incelendiğinde ortalama fide sürgün uzunluğu değerlerinin 0.63-2.66 cm arasında değiştiği, en yüksek fide sürgün uzunluğu ortalama değerinin kontrol x 100 ppm $\mathrm{GA}_{3}$ uygulamasında, en düşük fide sürgün uzunluğu ortalama değerinin ise 42 gün ön üşütme x 400 ppm $\mathrm{GA}_{3}$ uygulamasında saptandığı görülmektedir. En yüksek fide sürgün uzunluğu ortalama değeri kontrol x 100 ppm GA uygulamasından alınmış ve daha uzun süreli ön üşütme uygulamaları ve $\mathrm{GA}_{3}$ uygulamaları fide sürgün uzunluğu değerini olumsuz etkilemiştir.

Bulgularımız ön üşütme uygulamalarının fide sürgün uzunluğu değerini olumlu yönde etkilediğini bildiren bazı araştırmacıların (Şavşatlı ve Çatal, 2014; Tuncer ve Ummuhan, 2017) bulgularıyla benzerlik göstermektedir. Ayrıca, $\mathrm{GA}_{3}$ doz uygulamalarının fide sürgün uzunluğunu olumlu yönde etkilediğini bildiren bazı araştırmacıların (Özgen ve Arslan, 2016; Gürsoy, 2019) bulgularıyla da uyumludur.

\section{Fide kök uzunluğu}

Anadolu adaçayı fidelerinde kök uzunluğu $(\mathrm{cm})$ üzerine ön üşütme süreleri, $\mathrm{GA}_{3}$ doz uygulamaları ana etkilerinin ve ön üşütme süresi $x \mathrm{GA}_{3}$ dozları interaksiyon etkilerinin önemli düzeyde etkili olduğu saptanmıştır. Farklı ön üşütme süreleri ve $\mathrm{GA}_{3}$ dozlarında saptanan fide kök uzunluğu $(\mathrm{cm})$ ortalama değerleri ve oluşan gruplar Çizelge 4'te verilmiştir.

Çizelge 4'te, farklı ön üşütme sürelerine göre ortalama fide kök uzunluğu değerlerinin 3.52-4.63 $\mathrm{cm}$ arasında değiştiği, en yüksek fide kök uzunluğu ortalama değerinin 14 gün ön üşütme uygulamasında, en düşük fide kök uzunluğu ortalama değerinin ise 42 gün ön üşütme uygulamasında saptandığı; farklı $\mathrm{GA}_{3}$ uygulamalarına göre ortalama fide kök uzunluğu değerlerinin 2.97-4.85 cm arasında değiştiği, en yüksek fide kök uzunluğu ortalama değerinin 100 ppm uygulamasında, en düşük fide kök uzunluğu ortalama değerinin ise $400 \mathrm{ppm}$ uygulamasında saptandığı ve farklı ön üşütme süreleri $x \mathrm{GA}_{3}$ dozları birlikte etkileri incelendiğinde ortalama 
fide kök uzunluğu değerlerinin 0.63-5.86 cm arasında değiştiği, en yüksek fide kök uzunluğu ortalama değerinin kontrol x 100 ppm $\mathrm{GA}_{3}$ uygulamasında, en düşük fide kök uzunluğu ortalama değerinin ise 42 gün ön üşütme x 400 ppm $\quad \mathrm{GA}_{3} \quad$ uygulamasında saptandığı görülmektedir. En yüksek fide kök uzunluğu ortalama değeri kontrol $\times 100 \mathrm{ppm} \quad \mathrm{GA}_{3}$ uygulamasından alınmış ve daha uzun süreli ön üşütme uygulamaları ve $\mathrm{GA}_{3}$ uygulamaları fide kök uzunluğu değerini olumsuz etkilemiştir.

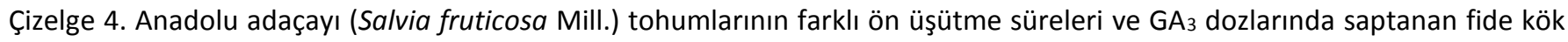
uzunluğu $(\mathrm{cm})$ ortalamaları ve oluşan gruplar

Table 4. Average seedling root length determined in the application of different stratification periods and gibberellic acid concentrations and created groups

\begin{tabular}{|c|c|c|c|c|c|}
\hline \multirow{2}{*}{$\begin{array}{l}\mathrm{GA}_{3} \text { dozları } \\
G A_{3} \text { doses }\end{array}$} & \multicolumn{4}{|c|}{$\begin{array}{l}\text { Ön üşütme süresi } \\
\text { Pre-chilling periods }\end{array}$} & \multirow{2}{*}{$\begin{array}{c}\text { Ortalama } \\
\text { Average }\end{array}$} \\
\hline & Kontrol/Control & 14 gün/day & 28 gün/day & 42 gün/day & \\
\hline Kontrol/Control & $5.37 a b$ & $4.38 \mathrm{~b}-\mathrm{e}$ & 4.03 def & $4.72 \mathrm{~b}-\mathrm{e}$ & $4.62 \mathrm{AB}$ \\
\hline 100 ppm & $5.86 a$ & $5.16 \mathrm{abc}$ & 4.26 cde & $4.12 \mathrm{c}-\mathrm{f}$ & $4.85 \mathrm{~A}$ \\
\hline 200 ppm & $4.28 \mathrm{~b}-\mathrm{e}$ & $4.47 \mathrm{~b}-\mathrm{e}$ & $3.77 \mathrm{~d}-\mathrm{g}$ & $3.96 \mathrm{~d}-\mathrm{g}$ & $4.12 \mathrm{BC}$ \\
\hline 300 ppm & $3.93 \mathrm{~d}-\mathrm{g}$ & $4.38 \mathrm{~b}-\mathrm{e}$ & $3.12 \mathrm{fg}$ & $4.15 c-f$ & $3.89 \mathrm{C}$ \\
\hline 400 ppm & $3.63 \mathrm{efg}$ & $4.77 \mathrm{a}-\mathrm{d}$ & $2.87^{1} \mathrm{~g}$ & $0.63^{2} \mathrm{~h}$ & $2.97 \mathrm{D}$ \\
\hline Ortalama/Average & $4.61 \mathrm{~A}$ & $4.63 \mathrm{~A}$ & $3.61 \mathrm{C}$ & $3.52 \mathrm{~B}$ & \\
\hline LSD (\%) & \multicolumn{5}{|c|}{$\begin{array}{l}0.43 \text { (Ön Üşütme Süresi/Pre-chilling periods) } 0.55 \text { (GA } A_{3} \text { Dozları/GA } A_{3} \text { doses) } 1.10 \text { (Ön üşütme süresi } \\
x \mathrm{GA}_{3} \text { dozları/Pre-chilling periods } x \mathrm{GA}_{3} \text { doses) }\end{array}$} \\
\hline
\end{tabular}

Bulgularımız, fide kök uzunluğu üzerine ön üşütme uygulamalarının istatistiksel olarak önemli düzeyde etkili olduğunu bildiren bazı araştırmacıların (Şavşatlı ve Çatal, 2014; Tuncer ve Ummuhan, 2017) bulgularıla uyumlu bulunmuştur.

Fide kök uzunluğu ortalama değerinin 100 ppm $\mathrm{GA}_{3}$ uygulamasına kadar artması ve daha yüksek dozlarda olumsuz yönde etkilenmesi, $\mathrm{GA}_{3}$ uygulamalarının çimlenme gücünü önemli düzeyde etkilemediğini bildiren Abacıoğlu (2019)'un ve $\mathrm{GA}_{3}$ doz uygulamalarının fide kök uzunluğunu olumlu yönde etkilediğini bildiren bazı araştırmacıların (Özgen ve Arslan, 2016;
Gürsoy, 2019) bulgularıyla kısmen uyumlu bulunmuştur.

\section{Fide kuru ağırlığı}

Anadolu adaçayı fidelerinde kuru ağırlık (mg) üzerine, ön üşütme süresi $x \quad G_{3}$ dozları interaksiyon etkilerinin önemli düzeyde etkili olduğu, ön üşütme süreleri ve $\mathrm{GA}_{3}$ doz uygulamalarının ise istatistiksel anlamda önemsiz olduğu belirlenmiştir. Farklı ön üşütme süreleri ve $\mathrm{GA}_{3}$ dozlarında saptanan fide kuru ağırlığı (mg) ortalama değerleri ve oluşan gruplar Çizelge 5 'te verilmiştir.

Çizelge 5. Anadolu adaçayı (Salvia fruticosa Mill.) tohumlarının farklı ön üşütme süreleri ve GA 3 dozlarında saptanan fide kuru ağırlığı (mg) ortalamaları ve oluşan gruplar

Table 5. Average dry seedling weight determined in the application of different stratification periods and gibberellic acid concentrations and created groups

\begin{tabular}{|c|c|c|c|c|c|}
\hline \multirow{2}{*}{$\begin{array}{l}\mathrm{GA}_{3} \text { dozları } \\
G A_{3} \text { doses }\end{array}$} & \multicolumn{4}{|c|}{$\begin{array}{l}\text { Ön üşütme süresi } \\
\text { Pre-chilling periods }\end{array}$} & \multirow{2}{*}{$\begin{array}{l}\text { Ortalama } \\
\text { Average }\end{array}$} \\
\hline & Kontrol/Control & 14 gün/day & 28 gün/day & 42 gün/day & \\
\hline Kontrol/Control & $6.08 a b$ & $5.53 \mathrm{~b}$ & $5.63 \mathrm{~b}$ & $6.26 a b$ & 5.87 \\
\hline 100 ppm & $6.03 a b$ & $6.20 a b$ & $5.60 \mathrm{~b}$ & $6.63 a b$ & 6.11 \\
\hline 200 ppm & $5.67 \mathrm{~d}$ & $5.93 a b$ & $6.30 a b$ & $6.86 a b$ & 6.19 \\
\hline 300 ppm & $6.83 a b$ & $5.93 a b$ & $5.93 a b$ & $5.56 \mathrm{~b}$ & 6.06 \\
\hline 400 ppm & $7.25 \mathrm{a}$ & $5.80 \mathrm{ab}$ & $5.73^{1} \mathrm{~b}$ & $3.33^{2} \mathrm{c}$ & 5.53 \\
\hline Ortalama/Average & 6.37 & 5.88 & 5.84 & 5.73 & \\
\hline LSD (\%) & \multicolumn{5}{|c|}{1.52 (Ön Üşütme Süresi x GA ${ }_{3}$ Dozları/Pre-chilling periods x GA3 doses) } \\
\hline
\end{tabular}


Çizelge 5'te, farklı ön üşütme süreleri $x \mathrm{GA}_{3}$ dozları birlikte etkileri incelendiğinde fide kuru ağırlığı ortalama değerlerinin 3.33-7.25 mg arasında değiştiği, en yüksek fide kuru ağırlığı ortalama değerinin kontrol x $400 \mathrm{ppm} \mathrm{GA}_{3}$ uygulamasından, en düşük fide kuru ağırlığı ortalama değerinin ise 42 gün ön üşütme $x 400$ ppm $\mathrm{GA}_{3}$ uygulamasından elde edildiği; farklı ön üşütme sürelerine göre fide kuru ağırlığı ortalama değerlerinin 5.73-6.37 mg arasında değiştiği, en yüksek fide kuru ağırlığı ortalama değerinin kontrol uygulamasında, en düşük fide kuru ağırlığı ortalama değerinin ise 42 gün ön üşütme uygulamasında saptandığı ve farklı $\mathrm{GA}_{3}$ dozlarına göre fide kuru ağırlığı ortalama değerlerinin 5.53$6.19 \mathrm{mg}$ arasında değiştiği ve en yüksek kuru ağırlığı ortalama değerinin 200 ppm $\mathrm{GA}_{3}$ uygulamasından elde edildiği görülmektedir. En yüksek fide kuru ağırlığı ortalama değeri kontrol $x$
400 ppm $\mathrm{GA}_{3}$ uygulamasından alınmış ve daha uzun süreli ön üşütme uygulamaları ve $\mathrm{GA}_{3}$ uygulamaları fide kuru ağırlığı değerini olumsuz etkilemiştir.

Elde ettiğimiz bulgular, $\mathrm{GA}_{3}$ doz uygulamalarının fide kuru ağırlığı değerlerini arttırdığını bildiren Mokhtarı (2016)'nın bulgularıla benzerlik göstermektedir.

\section{Sürgün kuru ağırlığı}

Anadolu adaçayı fidelerinde sürgün kuru ağırlığı (mg) üzerine, ön üşütme süreleri ve $\mathrm{GA}_{3}$ doz uygulamaları ana etkilerinin önemli düzeyde etkili olduğu, ön üşütme süresi $\mathrm{x} \mathrm{GA}_{3}$ dozları interaksiyon etkilerinin ise istatistiksel anlamda önemsiz olduğu saptanmıştır. Farklı ön üşütme süreleri ve $\mathrm{GA}_{3}$ dozlarında saptanan sürgün kuru ağırlığı (mg) ortalama değerleri ve oluşan gruplar Çizelge $6^{\prime}$ te verilmiştir.

Çizelge 6. Anadolu adaçayı (Salvia fruticosa Mill.) tohumlarının farklı ön üşütme süreleri ve GA3 dozlarında saptanan sürgün kuru ağırlığı (mg) ortalamaları ve oluşan gruplar

Table 6. Average dry sprout weight determined in the application of different stratification periods and gibberellic acid concentrations and created groups

\begin{tabular}{|c|c|c|c|c|c|}
\hline \multirow{2}{*}{$\begin{array}{l}\mathrm{GA}_{3} \text { dozları } \\
G A_{3} \text { doses }\end{array}$} & \multicolumn{4}{|c|}{$\begin{array}{l}\text { Ön üşütme süresi } \\
\text { Pre-chilling periods }\end{array}$} & \multirow{2}{*}{$\begin{array}{l}\text { Ortalama } \\
\text { Average }\end{array}$} \\
\hline & Kontrol/Control & 14 gün/day & 28 gün/day & 42 gün/day & \\
\hline Kontrol/Control & 3.60 & 2.76 & 2.43 & 2.63 & $2.85 \mathrm{BC}$ \\
\hline 100 ppm & 3.73 & 3.10 & 2.93 & 2.96 & $3.18 \mathrm{AB}$ \\
\hline 200 ppm & 3.76 & 2.96 & 3.43 & 3.40 & $3.39 \mathrm{~A}$ \\
\hline 300 ppm & 3.90 & 3.16 & 2.70 & 2.90 & $3.16 \mathrm{AB}$ \\
\hline 400 ppm & 3.93 & 2.66 & $2.76^{1}$ & $1.66^{2}$ & $2.75 \mathrm{C}$ \\
\hline Ortalama/Average & $3.78 \mathrm{~A}$ & $2.93 \mathrm{~B}$ & $2.85 \mathrm{~B}$ & $2.71 \mathrm{~B}$ & \\
\hline LSD (\%) & \multicolumn{5}{|c|}{0.50 (Ön üşütme süresi/Pre-chilling periods), 0.40 (GA $\mathrm{G}_{3}$ dozları/GA $A_{3}$ doses) } \\
\hline
\end{tabular}

${ }^{1}: 11$ fide ortalaması/Average of 11 seedlings, ${ }^{2}: 2$ fide ortalaması/Average of 2 seedlings

Çizelge 6'da, farklı ön üşütme sürelerine göre sürgün kuru ağırlığı ortalama değerlerinin 2.71$3.78 \mathrm{mg}$ arasında değiştiği, en yüksek sürgün kuru ağırlığı ortalama değerinin kontrol uygulamasında, en düşük sürgün kuru ağırlığı ortalama değerinin ise 42 gün ön üşütme uygulamasında saptandığı; farklı GA 3 uygulamalarına göre sürgün kuru ağırlığı ortalama değerlerinin 2.75-3.39 mg arasında değiştiği, en yüksek sürgün kuru ağırlığı ortalama değerinin 200 ppm uygulamasında, en düşük sürgün kuru ağırlığı ortalama değerinin ise 400 ppm uygulamasında saptandığı ve farklı ön üşütme süreleri $x \mathrm{GA}_{3}$ dozları birlikte etkileri incelendiğinde sürgün kuru ağırlığı ortalama değerlerinin 1.66-3.93 mg arasında değiştiği, en yüksek sürgün kuru ağırlığı ortalama değerinin kontrol x 400 ppm $\mathrm{GA}_{3}$ uygulamasında, en düşük sürgün kuru ağırlığı ortalama değerinin ise 42 gün ön üşütme $x 400$ ppm $\mathrm{GA}_{3}$ uygulamasında saptandığı görülmektedir. En yüksek sürgün kuru ağırlığı ortalama değeri kontrol x 400 ppm $\mathrm{GA}_{3}$ uygulamasından alınmış ve daha uzun süreli ön üşütme uygulamaları ve $\mathrm{GA}_{3}$ uygulamaları sürgün kuru ağırlığı değerini olumsuz etkilemiştir.

Bulgularımız, $\mathrm{GA}_{3}$ doz uygulamalarının sürgün kuru ağırlığını önemli düzeyde etkilediğini bildiren Gürsoy (2019)'un bulgularıyla uyumludur. 


\section{Kök Kuru Ağırı̆̆ı}

Anadolu adaçayı fidelerinde kök kuru ağırlığı (mg) üzerine ön üşütme süresi $x \mathrm{GA}_{3}$ dozları interaksiyon etkilerinin önemli düzeyde etkili olduğu, ön üşütme süresi ve $\mathrm{GA}_{3}$ doz uygulamaları ana etkilerinin ise istatistiksel anlamda önemsiz olduğu görülmüştür. Farklı ön üşütme süreleri ve $\mathrm{GA}_{3}$ dozlarında saptanan kök kuru ağırlığı (mg) ortalama değerleri ve oluşan gruplar Çizelge 7 'de verilmiştir.

Çizelge 7. Anadolu adaçayı (Salvia fruticosa L.) tohumlarının farklı ön üşütme süreleri ve GA dozlarında saptanan kök kuru ağırlığı (mg) ortalamaları ve oluşan gruplar

Table 7. Average dry root weight determined in the application of different stratification periods and gibberellic acid concentrations and created groups

\begin{tabular}{|c|c|c|c|c|c|}
\hline \multirow{2}{*}{$\begin{array}{l}\mathrm{GA}_{3} \text { dozları } \\
G A_{3} \text { doses }\end{array}$} & \multicolumn{4}{|c|}{$\begin{array}{l}\text { Ön üşütme süresi } \\
\text { Pre-chilling periods }\end{array}$} & \multirow{2}{*}{$\begin{array}{l}\text { Ortalama } \\
\text { Average }\end{array}$} \\
\hline & Kontrol/Control & 14 gün/day & 28 gün/day & 42 gün/day & \\
\hline Kontrol/Control & $2.27 \mathrm{de}$ & $2.76 \mathrm{a}-\mathrm{d}$ & $3.16 a b c$ & $3.60 \mathrm{a}$ & 2.94 \\
\hline 100 ppm & $2.36 \mathrm{~b}-\mathrm{e}$ & $3.33 a b$ & 2.63 a-e & $3.63 \mathrm{a}$ & 2.99 \\
\hline 200 ppm & $1.86 \mathrm{de}$ & $2.96 \mathrm{abc}$ & $2.86 a-d$ & $3.46 \mathrm{a}$ & 2.79 \\
\hline 300 ppm & 2.64 a-e & $2.43 \mathrm{~b}-\mathrm{e}$ & $3.20 \mathrm{abc}$ & 2.66 a-e & 2.73 \\
\hline 400 ppm & $3.35 a b$ & $2.76 \mathrm{a}-\mathrm{d}$ & $2.96^{1} a b c$ & $1.66^{2} \mathrm{e}$ & 2.68 \\
\hline Ortalama/Average & 2.49 & 2.85 & 2.96 & 3.00 & \\
\hline LSD (\%) & \multicolumn{5}{|c|}{1.03 (Ön üşütme süresi x GA 3 dozları/Pre-chilling periods $x$ GA 3 doses) } \\
\hline
\end{tabular}

Çizelge 7'de, farklı ön üşütme sürelerine göre kök kuru ağırlığı ortalama değerlerinin 2.49-3.00 mg arasında değiştiği, en yüksek kök kuru ağırlığı ortalama değerinin 42 gün ön üşütme uygulamasında, en düşük kök kuru ağırlığı ortalama değerinin ise kontrol uygulamasında saptandığı; farklı $\mathrm{GA}_{3}$ uygulamalarına göre kök kuru ağırlığı ortalama değerlerinin 2.68-2.99 mg arasında değiştiği, en yüksek kök kuru ağırlığı ortalama değerinin 100 ppm uygulamasında, en düşük kök kuru ağırlığı ortalama değerinin ise 400 ppm uygulamasında saptandığı ve farklı ön üşütme süreleri $\mathrm{x} \mathrm{GA}_{3}$ dozları birlikte etkileri incelendiğinde kök kuru ağırlığı ortalama değerlerinin 1.66-3.63 mg arasında değiştiği, en yüksek kök kuru ağırlığı ortalama değerinin 42 gün ön üşütme x 100 ppm $\mathrm{GA}_{3}$ uygulamasından, en düşük kök kuru ağırlığı ortalama değeri ise 42 gün ön üşütme $x 400$ ppm $\mathrm{GA}_{3}$ uygulamasında saptandığı görülmektedir. En yüksek kök kuru ağırlığı ortalama değeri 42 gün ön üşütme $x 100$ ppm $\mathrm{GA}_{3}$ uygulamasından alınmış ve daha kısa süreli ön üşütme uygulamaları kök kuru ağırlığı değerini olumsuz etkilemiştir. Kök gelişimi ön üşütmeden ve bir seviyeye kadar, artan $\mathrm{GA}_{3}$ uygulamasından olumlu yönde etkilenmiştir.

$\mathrm{GA}_{3}$ doz uygulamalarının kök kuru ağırlığını olumlu yönde etkilediğini bildiren Gürsoy (2019)'un bulgularıyla kısmen çelişmektedir. Bu durum, genotip farklılığından, tohumun canlılığından veya tohumun elde edildiği ana bitkinin maruz kaldığı yetiştirilme koşullarından kaynaklanabilir.

\section{Sonuçlar ve Öneriler}

Kontrollü koşullarda [\%70 nem, 25/15 ${ }^{\circ} \mathrm{C}$ (12 saat) sıcaklık ve 12 saat aydınlık/12 saat karanlık ortamda], Anadolu adaçayı (Salvia fruticosa Mill.) tohumlarının çimlenmesine farklı stratifikasyon ve $\mathrm{GA}_{3}$ uygulamalarının etkisinin belirlendiği bu çalışmada; Anadolu adaçayı tohumlarının çimlenme değerleri ve fide özellikleri üzerine, ön üşütme süreleri ana etkilerinin ve ön üşütme süresi $x \mathrm{GA}_{3}$ dozları interaksiyon etkilerinin önemli olduğu, en yüksek çimlenme gücü değeri 14 gün ön üşütme x 100 ppm $\mathrm{GA}_{3}$ uygulamasından elde edildiği saptanmıştır. Ayrıca, en yüksek fide sürgün uzunluğunun kontrol x 100 ppm GA uygulamasından, en yüksek fide kök uzunluğunun kontrol x 100 ppm $\mathrm{GA}_{3}$ uygulamasından, en yüksek fide kuru ağırlığının kontrol x 400 ppm GA GA $_{3}$ uygulamasından elde edilmiştir.

Tohumdan Anadolu adaçayı fidesi üretmek için çimlenme gücünün en yüksek tespit edildiği, 100 ppm $\mathrm{GA}_{3}$ ve 14 gün ön üşütme uygulaması ve hızlı 
bir çimlenme istendiğinde 14 gün ön üşütme $x$ 300 ppm GA $\mathrm{GA}_{3}$ uygulaması önerilebilir. Ayrıca, yalnızca stratifikasyon uygulaması yapılacaksa, 14 gün ön üşütme uygulaması veya sadece $\mathrm{GA}_{3}$ uygulaması yapılacaksa 100 ppm'de 24 saat bekletme uygulaması önerilebilir.

Salvia fruticosa Mill. (Anadolu adaçayı) tohumlarında çimlenme oranlarının arttırılması için diğer dormansi kırıcı uygulamaların da araştırılması gereklidir.

\section{Ekler}

Bu çalışma, HÜBAK Tarafından Desteklenen (Proje No: 19125), Yüksek Lisans Tezinden hazırlanmıştır.

\section{Çıkar Çatışması Beyanı: Makale yazarları} aralarında herhangi bir çıkar çatışması olmadığını beyan ederler.

Yazar Katkısı: AÖ çalışmayı tasarlayarak denemeleri kurmuş, $M B$ çalışmayı yürütmüş, $A O ̈$ verileri analiz etmiş, $A O ̈$ ve $M B$ makaleyi yazmıştır.

\section{Kaynaklar}

Abdollahi, J., Ebrahimi, M., Ramshini. H. A., Jaafari, A. A., Eftekhari, M., Mansouri, Y. S. \& Goharrizi, M.S.A.B. (2011). Seed germination as the major conservation issue of endemic Iranian Salvia species. Journal of Medicinal Plants Research, 6(1): 37-46.

Arabacı, O., Öğretmen, N. G., Tan, U. \& Yaşar, F. (2014). Effect of some seed treatments on germination of Sideritis perfoliata L. Trakya University Journal of Natural Sciences, 15(2): 83-87.

Arslan, D., Arslan, H., Cig, A. \& Bayraktar, Ö.V. (2017). Effects of treatments of gibberellic acid, cidric acid and stratification on germination of seeds of Salvia siirtica Kahraman, Celep \& Doğan Sp. Nov. (Lamiaceae). Journal of Applied Biological Sciences, 11(1): 29-32.

Abacıoğlu, E. (2019). Adaçayı (Salvia officinalis L.) tohumlarında hormon uygulamalarının çimlenme ve fidecik karakterlerine etkisi. Kastamonu Üniversitesi Fen Bilimleri Enstitüsü, Sürdürülebilir Tarım ve Tabii Bitki Kaynakları Ana Bilim Dalı, (Yayımlanmamış Yüksek Lisans Tezi), Kastamonu, s.67.

Bağçe, V. (2006). Bazı bitkisel hormonların Reseda lutea $L$. var. lutea bitkisinin tohum çimlenmesi üzerine etkileri. Selçuk Üniversitesi, Fen Bilimleri Enstitüsü, (Yayımlanmamış Yüksek Lisans Tezi), s.42, Konya.

Bayram, E. \& Sönmez, Ç. (2006). Adaçayı Yetiştiriciliği. E.Ü. Tar. Uyg. ve Araş. Merkezi Yayım Bülteni. No:48. ISSN
1300-3518, Bornova/izmir.

Çavuşoğlu, A., Sülüşoğlu, M., Samet, H., Çınar, N., Uysal, F. \& Erkal, S. (2010). Borik asit, gibberellik asit ve su uygulamalarının depolanmış aslankuyruğu (Leonurus cardiaca L.) tohumlarının çimlenmesi üzerine etkileri. II. Tıbbi ve Aromatik Bitkiler Sempozyumu, 23-25 Eylül, Yalova, s. 197-203.

Çalışkan, T., Maral, H., Akgül, M. \& Kırıcı, S. (2016). Giberelik asit uygulamalarının Urginea maritima (ada soğanı) tohumlarının çimlenmesi üzerine etkileri. III. Tıbbi ve Aromatik Bitkiler Sempozyumu, 4-6 Ekim Antalya, s. 19-23.

Dweck, A. (2000). The Folklore and Cosmetic Use of Various Salvia Species. In Sage: The Genus Salvia (Edited by Spiridon E. Kintzios). Harwood Academic Publishers, The Netherlands, 1-26.

Finch, W.E., Gray, D. \& Dickson, G.M. (1991). Germination responses of seven bedding plant species to environmental conditions and gibberallic acid. Seed Science and Technology, 19: 487-494.

Gürsoy, M. (2019). Farklı gibberellik asit dozlarının aspir (Carthamus tinctorius L.) çeşitlerinin çimlenme özellikleri üzerine etkisi. Uluslararası Gıda Tarım ve Hayvancılık Kongresi, 19-22 Eylül, Gaziantep, s. 395404.

Göztaş, T. (2008). Bazı bitkisel hormonların Centaurea kotschyi (Boiss. \& Heldr.) Hayek var. kotschyi bitkisinin tohum çimlenmesi üzerindeki etkilerinin araştırılması. Selçuk Üniversitesi, Fen Bilimleri Enstitüsü, (Yayımlanmamış Yüksek Lisans Tezi), Konya, 37s.

Göktürk, A., Ölmez, Z., Temel, F. \& Yahyaoğlu, Z. (2007). Bazı ön işlemlerin iğde (Elaeagnus angustifolia L.) tohumlarının çimlenmesi üzerine etkileri. Süleyman Demirel Üniversitesi Orman Fakültesi Dergisi, $A(2)$ : 37-41.

Hayta, E. \& Arabacı, O. (2011). Kekik olarak adlandırılan bazı bitki cinslerinin tohumlarında farklı çimlendirme yöntemlerinin belirlenmesi. ADÜ Ziraat Fakültesi Dergisi; 8(1): 91-101.

Karık, Ü. (2013). Marmara bölgesindeki Anadolu adaçayı (Salvia fruticosa Mill.) populasyonlarının morfolojik ve kalite özelliklerinin belirlenmesi, kültüre alınma olanaklarının araştırılması. Namık Kemal Üniversitesi Fen Bilimleri Enstitüsü Tarla Bitkileri Ana Bilim Dalı, (Yayımlanmamış Doktora Tezi), Tekirdağ, $139 \mathrm{~s}$.

Karık, Ü. \& Sağlam, A. C. (2017). Tekirdağ ekolojik koşullarında Anadolu adaçayı (Salvia fruticosa Mill.) popülasyonlarının verim ve kalite özelliklerinin belirlenmesi. Tarla Bitkileri Merkez Araştırma Enstitüsü Dergisi, 26(2): 203-215.

Karık, Ü. \& Sağlam, A. C. (2018). Marmara Bölgesi'ndeki Anadolu adaçayı (Salvia fruticosa Mill.) populasyonlarının uçucu yağ bileşenleri, toplam antioksidan aktivite, toplam fenolik ve flavonoid madde miktarlarının belirlenmesi. Anadolu, J. of AARI., 28(2): 37-47.

Kırıcı, S., Bayram, E., Tansı, S., Arabacı, A., Baydar, H., Telci, i., İnan, M., Kaya, D.A. \& Özel, A. (2020). Tıbbi ve aromatik bitkilerin üretiminde mevcut durum ve gelecek. Türkiye Ziraat Mühendisliği IX. Teknik Kongresi, 13-17 Ocak 2020, Bildiri Kitabı-1, 505-528.

Köse, H. (2000). Doğal bitki örtüsünde bulunan bazı odunsu 
peyzaj bitkilerinin tohum çimlendirme yöntemleri üzerinde araştırmalar. Anadolu, J. of $A A R I, 10(2)$ : 88100.

Mokhtari, N.E.P. (2016). Yaşlanmış gece safası (Oenothera biennis L.) tohumlarının çimlenmesi üzerine giberellik asitin etkilerinin belirlenmesi. Tarım Bilimleri Araştırma Dergisi 9(2): 23-25.

Özgen, Y. \& Arslan, N. (2016). Farklı gibberellik asit dozlarının ve uygulama sürelerinin Muscari azureum Fenzl (Keşişbaşı) tohumlarının çıkışına etkileri. Vı. Süs Bitkileri Kongresi, 19-22 Nisan, Antalya, s.313-318.

Özcan, İ., Arabacı, O. \& Öğretmen, N.G. (2014). Bazı adaçayı türlerinde farklı tohum çimlendirme uygulamalarının belirlenmesi. Türk Tarım-Gıda Bilimi ve Teknolojisi Dergisi, 2(5): 203-207.

Rivera, D., Obon, C. \& Cano, F. (1994). The botany, history and traditional uses of three-lobed sage (Salvia fruticosa Mill.) (Labiateae). Economic Botany, 48: 190-195

Subaşı, Ü. \& Güvensen, A. (2010). Nadir endemik Salvia smyrnaea Boiss. Lamiaceae tohumlarında çimlendirme çalışmaları. Biological Diversity and Conservation, 3(3): 126-132.

Şavşatlı, Y. \& Çatal, M.i. (2014). Düşük sıcaklıkta bekletme süresinin fesleğen (Ocimum basilicum L.) ve Altınçilekte (Physalis peruviana L.) tohumların çimlenmesi üzerine etkisi. Türkiye 5. Tohumculuk Kongresi, 19-23 Ekim, Diyarbakır, s.440-443.

Sönmez, Ç., Gökçöl, A., Şimşek Sosyal, A.Ö., Bayram, E. \& Çelen, A.E. (2019). Research on germination and emergence performance enhancing treatments on sage (Salvia Spp.) species. Turkish Journal of Agriculture, Food Science and Technology, 7(3): 504510.

Şehirali, S., 2002. Tohumluk ve teknolojisi. Trakya Üniversitesi Ziraat Fakültesi Tarla Bitkileri Bölümü. Yenilenmiş 3. Baskı, Fakülteler Matbaası, İstanbul.

Şenel, E. (2005). Bazı endemik bitki tohumlarının çimlenme şartlarının ve toplam fenolik madde içeriklerinin belirlenmesi üzerine araştırma. On Dokuz Mayıs Üniversitesi, Fen Bilimleri Enstitüsü, Biyoloji Anabilim Dalı (Yayımlanmamış Yüksek Lisans Tezi), Samsun, 52 S.

Topçu, G. (2006). Bioactive triterpenoids from Salvia L. Species. Journal of Natural Products, 69: 482-487.

Temel, M. \& Tokur, S. (2005). Bazı Origanum L. (Lamiaceae) taksonlarının tohum çimlenme davranışlarının belirlenmesi. Anadolu Üniversitesi Bilim ve Teknoloji dergisi, 6(2): 219-224.

Tulukçu, E. (2012). Bazı tıbbi bitki tohumlarının çimlenme özelliklerinin tespiti. Tarım Bilimleri Araştırma Dergisi, 5(1): 101-103.

Tuncer, B. \& Ummuhan, F. (2017). Molehiya (Corchorus olitorius L.) tohumlarındaki dormansi probleminin çözümüne yönelik araştırma. Türkiye Tarımsal Araştırmalar Dergisi, 4(3): 268-274.

Tursun, A.Ö. (2019). Salvia verticillata L. (Dadırak)'nin tohum dormansisinin kırılmasında farklı uygulamaların etkileri. KSÜ Tarım ve Doğa Dergisi, 22(Ek Sayı 1): 30-37.

Ünal, O., Gökçeoğlu, M. \& Topçuoğlu, Ş.F. (2004). Antalya endemiği Origanum türlerinin tohum çimlenmesi ve çelikle çoğaltılması üzerinde araştırmalar. Akdeniz Üniversitesi Ziraat Fakültesi Dergisi, 17(2): 135-147.

Weerakoon, W.L. \& Lovett, J.V. (1986). Studies of Salvia reflexa Hornem. III. Factors controlling germination. Weed Research, 26: 269-276.

Yılmaz, K. (2008). Avrupa Birliğine uyum çalışmaları ve Türk tohumculuk sektöründeki gelişmeler. Türkiye III. Tohumculuk Kongresi, 25-28 Haziran 2008, Nevşehir.

Yücel, E. \& Yılmaz, N. (2009). Effects of different alkaline metals salts $\left(\mathrm{NaCl}, \mathrm{KNO}_{3}\right)$, acid concentrations $\left(\mathrm{H}_{2} \mathrm{SO}_{4}\right)$ and growth regulator $\left(\mathrm{GA}_{3}\right)$ on the germination of Salvia cyaanescens. G.U. Journal of Science 22(3): 123-127.

Zeybek, N. \& Zeybek, U. (1994). Farmasötik Botanik, E.Ü. Eczacılık Fak. Yayınları, No. 2: 201s. 